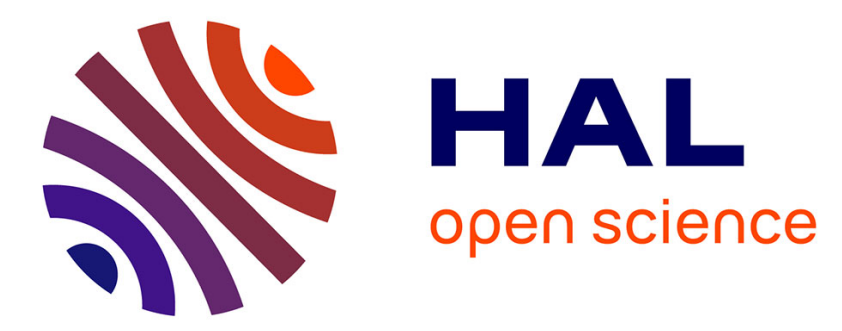

\title{
The secondary structure of the insect defensin A depends on its environment. A circular dichroism study
}

\author{
M Maget-Dana, J.M Bonmatin, C Hetru, M. Ptak, J Maurizot
}

\section{To cite this version:}

M Maget-Dana, J.M Bonmatin, C Hetru, M. Ptak, J Maurizot. The secondary structure of the insect defensin A depends on its environment. A circular dichroism study. Biochimie, 1995, 77 (4), pp.240-4. 10.1016/0300-9084(96)88130-2 . hal-02082593

\section{HAL Id: hal-02082593 \\ https://hal.science/hal-02082593}

Submitted on 13 Oct 2021

HAL is a multi-disciplinary open access archive for the deposit and dissemination of scientific research documents, whether they are published or not. The documents may come from teaching and research institutions in France or abroad, or from public or private research centers.
L'archive ouverte pluridisciplinaire HAL, est destinée au dépôt et à la diffusion de documents scientifiques de niveau recherche, publiés ou non, émanant des établissements d'enseignement et de recherche français ou étrangers, des laboratoires publics ou privés.

\section{(c)(1)}

Distributed under a Creative Commons Attribution| 4.0 International License 


\title{
The secondary structure of the insect defensin A depends on its environment. A circular dichroism study
}

\author{
R Maget-Dana ${ }^{\mathrm{a}}$, JM Bonmatin ${ }^{\mathrm{a}}$, Ch Hetrub, M Ptak ${ }^{\mathrm{a}}$, JC Maurizot ${ }^{\mathrm{a}}$ \\ aCentre de Biophysique Moléculaire (CNRS), Université d'Orléans, 1A, avenue de la Recherche Scientifique, \\ 45071 Orléans Cedex 2; \\ Institut de Biologie Moléculaire et Cellulaire (CNRS), UPR 9022, Réponse immunitaire et développement chez les insectes, \\ 15, rue René Descartes, 67084 Strasbourg Cedex, France
}

\begin{abstract}
Summany - Defensin A is an inducible antibacterial protein isolated from the larvae of Phormia terranovae. The conformation of defensin $A$ has been previously determined by two-dimensional ${ }^{1} \mathrm{H}-\mathrm{NMR}$ for concentrations in the range of $4-8 \mathrm{mM}$ in water (Bonmatin JM et al (1992) J Biomol NME 2, 235-256). CD spectroscopic data of defensin A at lower concentrations (10-5 to 10-3 M) are reported herein. The ellipticity in ilie $200-240 \mathrm{~nm}$ wavelength ran $\mathrm{e}$ for various solvents varies as follows: acetonitrile < water < methanol < HFIP. The magnitude of $\left|\Theta_{222}\right|$ is strongly dependent on defensiiz corcentration in a buffer solution, suggesting an aggregation process. Tr: 1 . lical content of defensin $A$ is maximum at a pH value range $(7.5-\widehat{3})$ for which the optimum antibacterial activity was obsierved (Cociancich S et al (1993) J Biol Chem 268, 19239-19245).
\end{abstract}

defensin A / insect defensin / antibacterial protein / secondary structure / oligomerisation / circular dichroism

\section{Introduction}

Insect defensins are inducible antibacterial proteins produced in response to bacterial injuries and secreted in the insect hernolyniph [1]. Defensin $A$ has been isolated and characterizid from the larvae of the fleshfly Phormia terranovae [2]. It is a small (40 residues) cationic protein, representative of a large family of insect defense proteins. Its conformation in water has already been determined by using 2D ${ }^{1} \mathrm{H}-\mathrm{NMR}$ associated with modeling techniques $[3,4]$. Defensin $A$ is organized in three distinct regions: a C-terminal antiparallel $\beta$-sheet linked to an amphipatic $\alpha$-helix via two S-S bridges and a $\mathrm{N}$-terminal loop linked to the $\beta$ sheet by the third S-S bridge (fig 1). Defensin A behaves as an amphipathic protein able to spread as a monolayer at the air/water interface, and interacts with membrane lipids [5] by forming voltage dependent channels [6].

Here we report circular dichroism (CD) data showing that the secondary structure of defensin A depends on the solvent nature and on the protein concentration, $\mathrm{pH}$ and presence of salts in aqueous solutions.

\section{Materials and methods}

Recombinant insect defensin $A$ was prepared by Transgène (Strasbourg, France). Pure water was obtained from a Millipore
(Milli Q) apparatus. Methanol and acetonitrile were purchased from BDH and hexafluoroisopropanol (HFIP) from Merck.

Concentrations of defensin A were calculated from the absorbance at $275 \mathrm{~nm}$ using $\varepsilon=1400 \mathrm{M}^{-1} \mathrm{~cm}^{-1}$ for the single Tyr29 chromophore. CD spectra were recorded at room temperature on a Jobin-Yvon IV autodichrograph using, 0.1 or $0.01 \mathrm{~cm}$ path length in order to measure absorbance values less than 1 on the whole range of wavelengths. Optical activities were reported as ellipticity per amino acid residue: $\Theta_{\text {res }}$ (unit: deg $\left.\mathrm{cm}^{2} \mathrm{dmol}^{-1}\right)$. The $\alpha$-helical content was roughly estimated from $C D$ data according to the formula: $\% \alpha$-helix $=$ $\Theta_{222} / 3298 \times(-10)$ given by Zhong and Johnson on the basis of a 26-protein data set [7].

\section{Results}

\section{Nature of the solvent}

$C D$ spectra of defensin $A$ in various solvents are presented in figure 2 . In acetonitrile the spectrum was characterized by a weak positive band near $200 \mathrm{~nm}$ and a weak negative band centered at $228 \mathrm{~nm}$. The spectrum obtained in water presented a negative band at $207 \mathrm{~nm}$ and a shoulder near $221 \mathrm{~nm}$. Spectra obtained in HFIP and methanol had comparable shapes: a negative band centered near $208 \mathrm{~nm}(210 \mathrm{~nm}$ for methanol) and a negative shoulder near $218 \mathrm{~nm}$ (221 nm for methanol). 


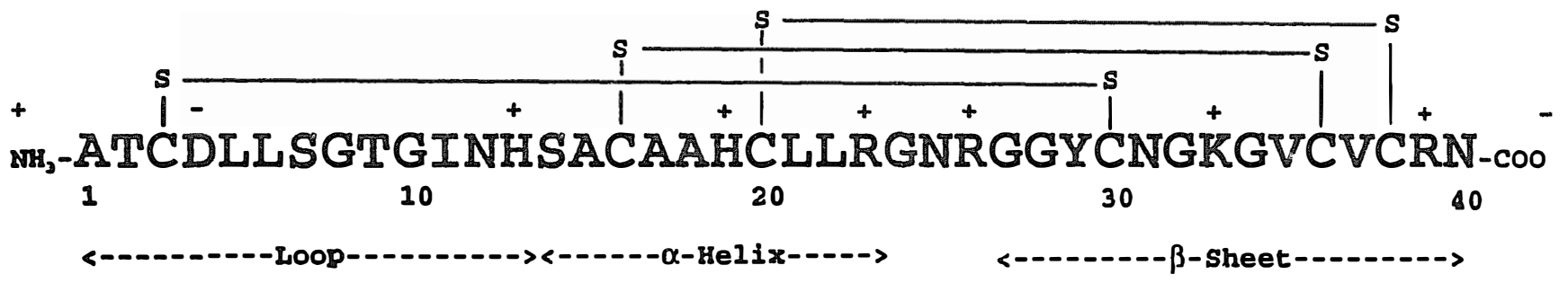

Fig 1. Primary sequence of defensin A. Structure elements as determined by $2 \mathrm{D}{ }^{1} \mathrm{H}-\mathrm{NMR}$ and molecular modeling are indicated. They correspond to $15 \%$ for the turns, $25 \%$ for the strands, $27 \%$ for the $\alpha$-helix, and $33 \%$ for the mobile loop. Experimental conditions were: 5 to $9 \%$ defensin $\mathrm{A}$ in water, $\mathrm{pH} 4.9$, temperature from 22 to $33^{\circ} \mathrm{C}$.

The intensity of the negative dichroic bands increased in the following order: acetonitrile $<$ water $<$ methanol $<$ HFIP. At a fixed concentration of $3.2 \times 10^{-5} \mathrm{M}$ and according to the ellipticity at $222 \mathrm{~nm}$, the $\alpha$-helix content was estimated to be about $15 \%$ in water and $20 \%$ in HFIP [7].

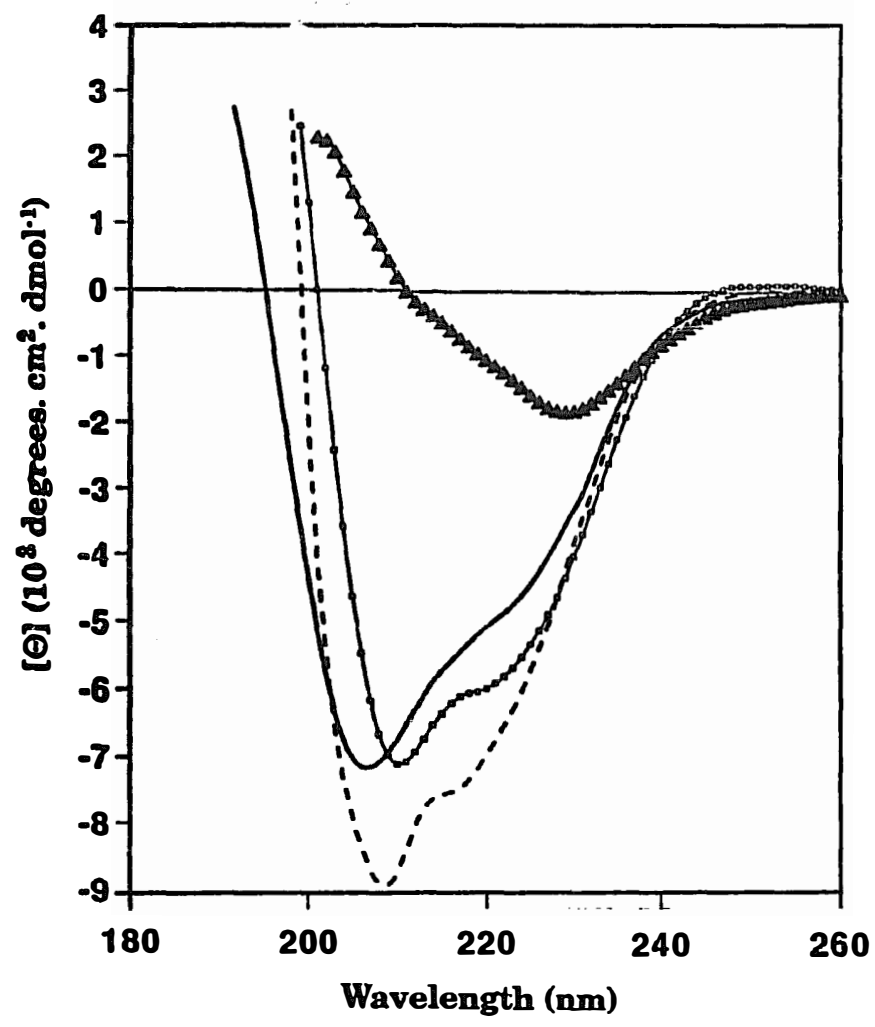

Fig 2. $C D$ spectra of defensin $A$ in various solvents. (- $-\Delta-)$ acetonitrile; (Defensin A concentration: $3.210^{-5} \mathrm{M}$.
Aqueous solutions of defensin A: effect of concentration

Figure 3a presents CD spectra of defensin $A$ recorded for various concentrations in a $30 \mathrm{mM}$ phosphate buffer ( $\mathrm{pH}$ 7.5). They look like those observed in water, with a strong negative band between 206 and $209 \mathrm{~nm}$ and a negative shoulder at around $222 \mathrm{~nm}$. Clearly, intensities of the dichroic bands strongly depended on the defensin concentration since the magnitude of $\left|\Theta_{222}\right|$ increased from $\approx 3700 \mathrm{deg} \mathrm{cm}^{2}$ $\mathrm{dmol}^{-1}$ at $10^{-5} \mathrm{M}$ to $\approx 7000 \mathrm{deg} \mathrm{cm}^{2} \mathrm{dmol}^{-1}$ at $10^{-3} \mathrm{M}$ (fig 3b). These values correspond to an $\alpha$-helix content of about 11 and $20 \%$ respectively. A red-shift of the first minimum was also observed from 206 to $209 \mathrm{~nm}$. These features demonstrate changes in the secondary structure of defensin $A$ in the $\mu \mathrm{M}-\mathrm{mM}$ concentration range and suggest an aggregation process which participates in the structuration of defensin A.

\section{Effect of $p H$}

CD spectra of defensin A were recorded for $\mathrm{pH}$ values between 3.3 and 10.6. Data in figure 4a show that band intensities were strongly dependent on $\mathrm{pH}$ whereas the global shape was conserved. The plot of $\left|\Theta_{222}\right|$ versus $\mathrm{pH}$ plot in figure $4 \mathrm{~b}$ indicates that the helical content was very low at $\mathrm{pH} 3.3$ and reached a maximum near $\mathrm{pH}$ 7.5-8.

\section{Effect of monovalent and divalent cations}

No significant variation in ellipticity was detected when the buffer (Tris) molarity was raised from 5 to $30 \mathrm{mM}$ but, as shown in figure 5a, addition of $\mathrm{KCl}$ led to a large decrease of the ellipticity of defensin A solutions. Ellipticity flattens out at $68 \%$ of its initial value when $50 \mathrm{mM} \mathrm{KCl}$ were added (fig $5 \mathrm{~b}$ ). When the maximum $\mathrm{KCl}$ effect was reached, a supplementary addition of $\mathrm{CaCl}_{2}$ led to a further decrease of the 

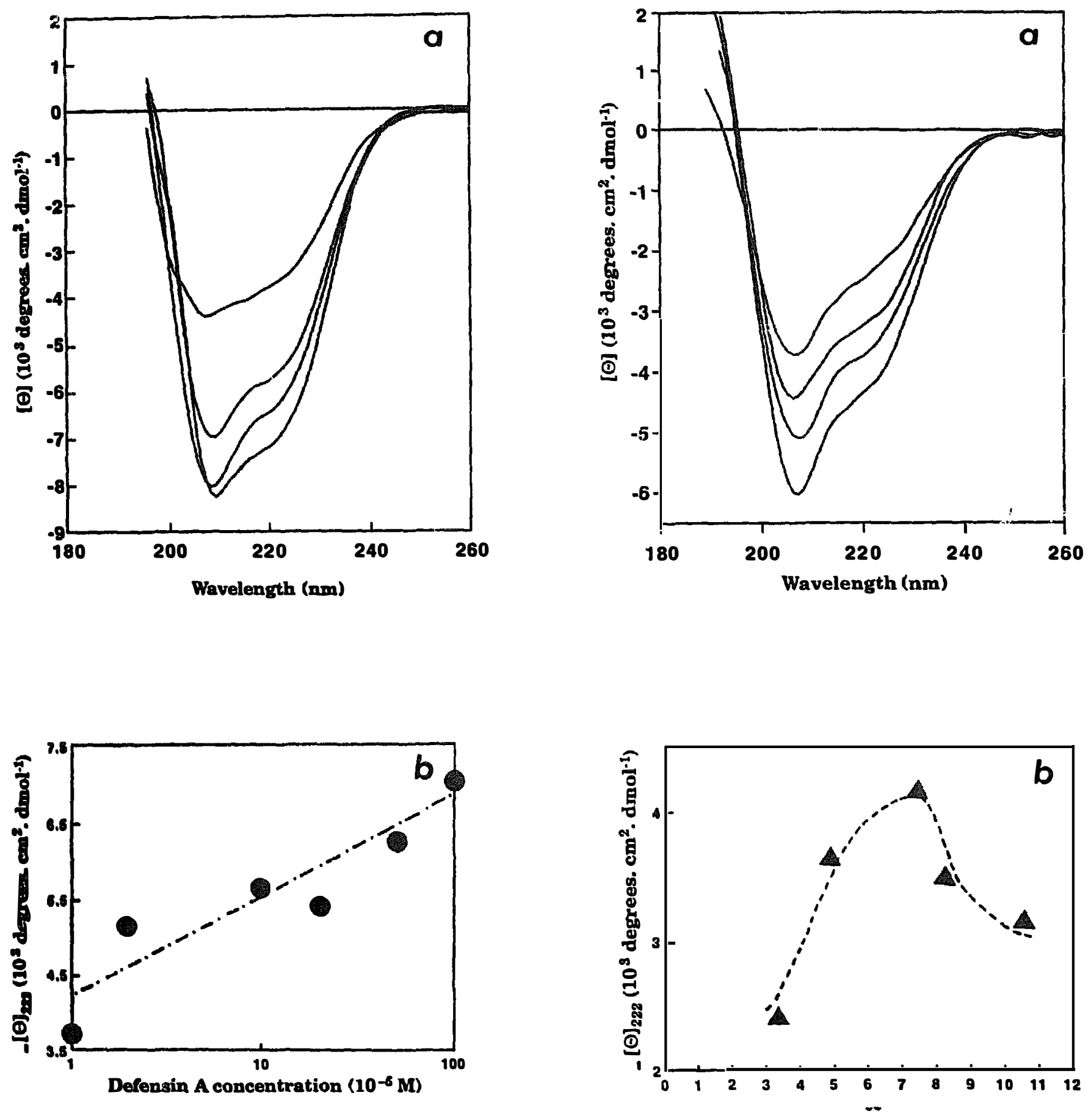

Fig 3. Effect of concentration on the secondary structure of defensin A. a. CD spectra of defensin $A$ as a function of concentration. From top to bottom: $10^{-5} \mathrm{M}, 10^{-4} \mathrm{M}, 5 \times$ $10^{-4} \mathrm{M}$, and $10^{-3} \mathrm{M}$ in $30 \mathrm{mM}$ phosphate buffer ( $\mathrm{pH} 7.5$ ). b. $\left|\theta_{222}\right|$ as a function of defensin A concentration.

Fig 4. Effect of $\mathrm{pH}$ on the secondary structure of defensin A. a. CD spectra of defensin $A$ as a function of $\mathrm{pH}$ in $5 \mathrm{mM}$ Tris buffers. From top to bottom: $\mathrm{pH} 3.3,10.6,4.9$, and 7.5. Defensin A concentration: $2 \times 10^{-5} \mathrm{M}$. b. $\left|\Theta_{222}\right|$ as a function of $\mathrm{pH}$. 

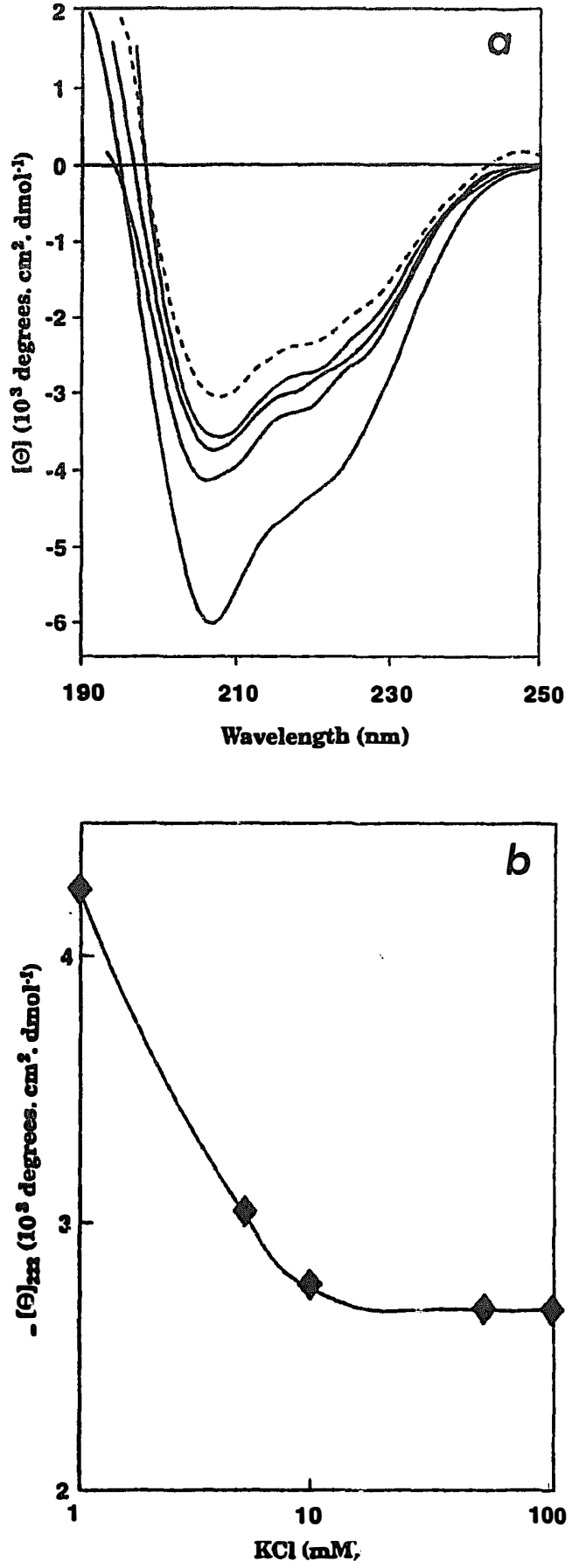

Fig 5. Effect of salts on the secondary structure of defensin A. a. CD spectra of defensin $A$ as a function of $\mathrm{KCl}$ concentration. $2 \times 10^{-5} \mathrm{M}$ defensin $\mathrm{A}$ in $5 \mathrm{mM}$ Tris $(\mathrm{pH}$ 7.5). $\mathrm{KCl}$ concentration from bottom to top: $0,5,10$, and $100 \mathrm{mM}$. (- - ) additional effect of $5 \mathrm{mM} \mathrm{CaCl} 2(100 \mathrm{mM}$ $\mathrm{KCl}+5 \mathrm{mM} \mathrm{CaCl} 2) \cdot \mathrm{b} \cdot\left|\Theta_{222}\right|$ as a function of $\mathrm{KCl}$ concentration. ellipticity $(-13 \%$ for $5 \mathrm{mM} \mathrm{CaCl}$ ) (fig $5 a$ ). From all these features, the ellipticity appears related to the presence of salts with a possible specific effect of $\mathrm{Ca}^{2+}$, but this independent from the ionic strength change.

\section{Discussion}

This study illustrates the great sensitivity of the secondary structure of defensin A to environmental conditions. CD spectra show clearly the solvent dependence of the helical content as monitored by $\left|\Theta_{222}\right|$. It is not surprising that the higher helical content was observed in HFIP since this solvent is known as a structurepromoting solvent [8] in contrast to acetonitrile in which defensin A is weakly structured. Intermediate situations which clearly demonstrated the presence of an $\alpha$-helix were observed for water and methanol.

The propensity of defensin A to self-associate was previously demonstrated both by surface tension measurements (Maget-Dana, Ptak, in preparation) and by fluorescence polarization experiments of the single Tyr residue as a function of viscosity (Talbot JC, personal communication). In this study, the dependence of the helicity percentage on defensin concentration clearly indicates that oligomerization plays a major role on the secondary structure formation. A helical content of about $20 \%$ at $10^{-3} \mathrm{M}$ as extracted from the present study is in good agreement with the $25 \%$ value determined unambiguously from NMR data in the same range of concentrations [3]. It is likely that this would be the maximum amount of helical content induced by the defensin oligomerization. In dilute solutions, we can assume that the helix fragment (16-20) between the two S-S bridges is invariant and corresponds to the $\approx 10 \%$ of $\alpha$-helix content found at $10^{-5} \mathrm{M}$. It can be noticed that the well resolved signals detected in NMR experiments carried out at $\mathrm{mM}$ concentrations [3] ruled out the presence of large defensin A oligomers. Therefore, the evolution of the dichroic intensity as a function of defensin A concentration would more corcespond to an increased amount of small oligomers than to oligomers growing in size.

Secondary structure is also very sensitive to other environmental parameters such as $\mathrm{pH}$ or the presence of mono- and divalent cations. As far as the $\mathrm{pH}$ is concerned, the maximum helical content was detected in the $\mathrm{pH}$ range 7-8 corresponding to the deprotonation of the two His residues $(\mathrm{p} K \sim 7)$. From NMR data [3], His13 was located just before the beginning of the helix whereas His19 belonged to the first turn of the helix. Thus, the ionisation state of the His residues may have a great influence on the secondary structure of defensin A. The other ionisable group involved in the helix (Arg23) is always protonated $(p K \sim 12)$ in 
the $\mathrm{pH}$ range of this study. We can also consider that, in addition to a direct influence on defensin $A$ folding, the $\mathrm{pH}$ of the solution might affect, as a first event, the associated state of defensin and, as a consequence, the helix content. This is consistent with the observation that the $\mathrm{pH}$ for the maximum helicity corresponds also nearly to the isoelectric point of defensin A (calculated $\mathrm{p} I=8.3)$. At this $\mathrm{pH}$ the electrostatic repulsions between defensin A molecules are weak and self-association should be favoured. Besides, the bell-shape of the curve (fig $4 \mathrm{~b}$ ) is in favour of a relation between the global charge of the protein and the helicity. Finally, the maximum helicity corresponds to a $\mathrm{pH}$ range where His residues are deprotonated and where the global charge of defensin $\mathrm{A}$ is weak. The $\mathrm{KCl}$ effect might be analyzed with respect to the self-association process as well. As a matter of fact, it has been shown that defensin A has less tendency to self-associate in the presence of monovalent salts [9]. Here, the loss of ellipticity observed in the presence of $\mathrm{KCl}$ might be a consequence of the dissociation of defensin A oligomers.

The optimum antibacterial activity has been observed at a $\mathrm{pH}$ ranging between 7.5 and 8 [6]. This is the $\mathrm{pH}$ range for which we found a maximum helical content. Therefore, the biological activity of defensin A seems to be closely dependent on its secondary structure and may be on its autoassociation state since both appeared correlated.

\section{Acknowledgments}

We thank JC Talbot for fruitful discussions and Professor $J$ Hoffmann for his interest in this work.

\section{References}

1 Hoffmann J, Hetru C (1992) Insect defensins: inducible antibacterial peptides. Immunol Today 13, 411-415

2 Lambert J, Keppi E, Dimarcq JL, Wicker C, Reichhart JM, Dunbar B, Lepage P, Van Dorsselaer C, Hoffmann J, Forthergill J Hoffmann D (1989) Insect immunity: isolation from immune blood of the dipteran Phormia terranovae of two insect antibacterial peptides with sequence homology to rabbit lung macrophage bactericidal peptides. Proc Natl Acad Sci USA 86, 262-266

3 Bonmatin JM, Bonnat JL, Gallet X, Vovelle F, Ptak M, Reichhart JM, Hoffmann J, Keppi E, Legrain M, Achestelter T (1992) Two-dimensional 'H NMR study of recombinant insect defensin in water: resonance assignements, secondary structure and global folding. J Biomol NMR 2, 235-256

4 Bonmatin JM, Genest M, Petit MC, Gincel E, Simorre JP, Cornet B, Gallet X, Caille A, Labbé H, Vovelle F, Ptak M (1992) Progress in multidimensional NMR investigations of peptide and protein 3-D structures in solution. From structure to functional aspects. Biochimie 74, 825-836

5 Maget-Dana R, Hetru Ch, Hoffmann JA, Ptak M (1993) Adsorption of defensin $A$, an insect antibacterial protein, to model membranes. Abstracts of 2nd IUBMB Conference on Biochemistry of Cell Membranes. Bari (Italy) Sept 29-Oct 3

6 Cociancich S, Ghazi A, Hetru C, Hoffmann JA, Letellier L (1993) Insect defensin, an inducible antibacterial peptide, forms voltage-dependent channe! in Micrococcus luteus. J Biol Chem 268, 19239-19245

7 Zhong L, Johnson WC (1992) Environment affects amino acid preference for secondary structure. Proc Natl Acad Sci USA 89, 4462-4465

8 Perczel A, Hollosi M, Foxman BM, Fasman GD (1991) Conformational analysis of Pseudocyclic hexapeptides based on quantitative circular dichroism (CD), NOE, and X-ray Data. The pure CD spectra of type I and type II B-turns. J Am Chem Soc 113, 9772-9784 